\title{
PREDIKTOR SYMPTOMATIC INTRACEREBRAL HEMORRHAGE PASCATROMBOLISIS INTRAVENA PADA STROKE ISKEMIK AKUT
}

\author{
PREDICTORS OF SYMPTOMATIC INTRACEREBRAL HEMORRHAGE \\ FOLLOWING INTRAVENOUS THROMBOLYSIS IN ACUTE ISCHEMIC STROKE
}

Al Rasyid, * Salim Harris, * Mohammad Kurniawan, * Rakhmad Hidayat, * Taufik Mesiano*

\begin{abstract}
Despite its effectiveness, the percentage of ischemic stroke patients who received definitive treatment, thrombolysis, never went above 10\%, due to one of the reason is the occurrence of severe, post-therapeutic complications, such as symptomatic intracerebral hemorrhage (sICH). Several factors contribute to sICH occurrence are age, severity of stroke, early changes of ischemic sign, hyperglycemia, blood pressure, antiplatelet use and its interval. Patients with highest risk of sICH has been shown to have the greatest benefits from thrombolysis among other subgroup patients, therefore withholding therapy is not a choice. Compliance to the stroke's guidelines could reduce the risk of complications as well as boost effectiveness of treatment.
\end{abstract}

Keywords: Safety predictors, acute ischemic stroke, thrombolysis, sICH

\section{ABSTRAK}

Walau terbukti efektif, persentase pasien yang dapat dilakukan tindakan definitif stroke iskemik akut berupa trombolisis tidak pernah mencapai angka $10 \%$, salah satunya disebabkan pertimbangan terhadap komplikasi berat, seperti symptomatic intracerebral hemorrhage (sICH). Beberapa faktor yang berpengaruh terhadap kejadian sICH antara lain usia, derajat stroke, perubahan tanda iskemik dini, hiperglikemia dan diabetes melitus, tekanan darah, penggunaan antiplatelet, serta waktu pemberian. Pasien dengan risiko sICH tertinggi memiliki keuntungan terbesar dari trombolisis sehingga menunda tindakan bukanlah suatu opsi. Kepatuhan terhadap panduan tindakan dapat mengurangi angka kejadian komplikasi berat.

Kata kunci: Prediktor keamanan, stroke iskemik akut, trombolisis, sICH

*Divisi Neurovaskular Departemen Neurologi FK Universitas Indonesia/RSUPN Dr. Cipto Mangunkusumo, Jakarta. Korespodensi: alrasyid50@yahoo.com.

\section{PENDAHULUAN}

Stroke masih menjadi salah satu penyebab kematian dan kecacatan tertinggi di seluruh dunia. Menurut laporan American Heart Association/ American Stroke Association (AHA/ASA) terdapat 6,5 juta kasus kematian akibat stroke di seluruh dunia di tahun 2013. ${ }^{1}$ Menurut perkiraan, 1 dari 6 orang di dunia akan mengalami minimal satu kali serangan stroke pada hidupnya. ${ }^{2}$ Dengan demikian, populasi yang terdampak oleh stroke, atau overall stroke burden, akan terus meningkat, sesuai tren yang dijumpai sepanjang 1990 hingga 2013. ${ }^{3}$

Penggunaan trombolisis dalam tata laksana stroke iskemik akut telah dikenal lama, serta terbukti efektif, baik dari segi prognosis penyakit dan biaya. Namun ternyata penggunaan intravenous tissue plasminogen activator (IV-tPA) masih rendah, bahkan di negara maju. Penyebab utama hal ini ialah sulitnya melakukan tindakan pada periode emas (golden period) 3-4,5 jam sejak awitan stroke. ${ }^{4-5}$ Efek terapeutik trombolisis akan berkurang seiring bertambahnya waktu antara awitan stroke dan tindakan. ${ }^{6}$ Semakin cepat dilakukan, maka angka mortalitas dan kejadian perdarahan intrakranial berkurang secara signifikan dan luaran fungsi pasien menjadi lebih baik.?

Salah satu pertimbangan klinisi dalam menunda terapi trombolisis adalah potensi komplikasi berupa perdarahan intraserebral simtomatik atau symptomatic intracerebral hemorrhage (sICH). Dibandingkan ICH spontan, sICH cenderung berukuran besar dan multifokal. ${ }^{8}$ Komplikasi ini terjadi pada $2-9 \%$ pasien yang menjalani tindakan, dengan angka mortalitas mencapai $50 \% .{ }^{9-10}$ Beberapa studi membuat sistem skor untuk mengidentifikasi pasien yang berisiko tinggi mengalami sICH. Parameter yang dipakai di tiap studi merupakan faktor-fakor risiko yang telah lama dikaitkan dengan 
kejadian perdarahan intrakranial, seperti usia, tekanan darah, glukosa darah, dan lain-lain. ${ }^{11}$

Walau nilai prediktif tiap studi masih membutuhkan validasi lebih lanjut, penggunaan sistem skor diharapkan dapat meningkatkan angka penggunaan trombolisis sekaligus mengurangi risiko terjadinya komplikasi sICH. Tinjauan pustaka ini dibuat untuk membahas prediktor terjadinya sICH berdasarkan parameter yang tercantum dalam berbagai studi.

\section{PEMBAHASAN}

\section{Symptomatic Intracerebral Hemorrhage dan Faktor Risiko}

Menurut uji National Institute of Neurological Disorders and Stroke (NINDS), sICH adalah perdarahan yang terlihat pada CT scan dalam jangka 36 jam pascatindakan trombolisis dan tampak gejala klinis pada pasien akibat lesi intraserebral tersebut. ${ }^{12}$ Berdasarkan uji yang dilakukan oleh NINDS, didapatkan prevalensi sICH sebanyak $6,4 \%$ dari seluruh pasien yang menjalani terapi trombolisis, serta $0,6 \%$ pada pasien yang diberikan plasebo. ${ }^{12}$ Sementara itu, studi European Cooperative Acute Stroke Study (ECASS) III, sICH adalah perdarahan yang terlihat dari CT scan atau MRI, terkait gambaran klinis defisit neurologis pada pasien, yang ditandai dengan peningkatan skor National Institute of Heart Stroke Scale (NIHSS) sebanyak $\geq 4$ atau mengakibatkan kematian. ${ }^{5}$ Pada studi ini, prevalensi sICH jauh lebih rendah, yaitu 2,4\% pada kelompok pascatrombolisis dan $0,2 \%$ pada kelompok plasebo. ${ }^{5}$

Laporan studi klinis dan data register terkini, insiden $\mathrm{SICH}$ pascapemberian alteplase dosis standar $0,9 \mathrm{mg} / \mathrm{kgBB}$ adalah $2-7 \%$, dan diduga berkaitan dengan dosis yang dipakai. ${ }^{13}$ Komplikasi inilah yang menyebabkan klinisi di bidang emergensi menolak atau menunda melakukan tindakan trombolisis, sekalipun prevalensi kejadian sICH tidak terlalu tinggi dan tersedia fasilitas medik yang memadai. ${ }^{14}$

Oleh karena itu, para peneliti membuat berbagai prediktor sICH pasca-tPA. Pada umumnya, prediktor yang dipakai memakai kombinasi 5 aspek, yaitu riwayat penyakit dan terapi, temuan klinis, data pemeriksaan lab, terapi spesifik, dan gambaran CT scan. ${ }^{15}$ Sebuah systematic review dan metaanalisis dari 55 studi terkait perdarahan intrakranial menyatakan usia tua, derajat stroke, kadar glukosa awal, hipertensi, penyakit jantung iskemik, gangguan fungsi ginjal, diabetes melitus, penyakit jantung kongestif, fibrilasi atrium, riwayat penggunaan antiplatelet, leukoaraiosis, dan infark pada CT scan berhubungan dengan peningkatan risiko $\mathrm{sICH} .{ }^{16}$

Usia lanjut telah lama dihubungkan dengan komorbiditas yang lebih sering dan luaran yang lebih buruk, tanpa memperhatikan komplikasi tPA. Pada studi NINDS, pasien berusia $\geq 80$ tahun berisiko 2,87 kali lebih tinggi mengalami sICH. ${ }^{17}$ Adapun uji ECASS III menunjukkan usia $\geq 65$ tahun menjadi faktor risiko sICH, walau tidak memengaruhi hasil luaran klinis. ${ }^{18}$ Berdasarkan panduan AHA/ ASA tahun 2018 tentang tata laksana stroke akut, rekomendasi terkuat untuk tindakan trombolisis adalah $\geq 18$ tahun bila dilakukan $\leq 3$ jam dari awitan, dan $\leq 80$ tahun bila 3-4,5 jam dari awitan. ${ }^{4}$

Derajat stroke berdasarkan skor NIHSS telah lama dihubungkan dengan luaran yang lebih buruk. Wahlgren dkk mendapatkan derajat stroke menjadi prediktor independen $\mathrm{sICH}$ pascatrombolisis intravena atau intra-arterial, dengan rasio Odds (RO) sebesar 1,8. ${ }^{19}$ Studi Liu dkk, menunjukkan bahwa skor NIHSS $>20$ saat kedatangan adalah faktor risiko sICH..$^{20}$ American Heart Association/American Stroke Association merekomendasikan tindakan trombolisis pada pasien dengan skor NIHSS $\leq 25 .{ }^{4}$

Beberapa gambaran CT scan telah diketahui memiliki korelasi dengan pembentukan sICH dan luaran yang lebih buruk. Perubahan tanda iskemik dini atau early ischemic changes (EIC), seperti hipodensitas, hilangnya diferensiasi substansia grisea-alba, dan edema serebral. Early ischemic changes dapat dikuantifikasi melalui beragam instrumen, contohnya skor Alberta Stroke Programme Early CT Score (ASPECTS) dengan nilai $\leq 7$ berisiko 4,6 kali lebih tinggi terjadinya sICH. ${ }^{21}$ Analisis univariat dari studi Bentley dkk juga menunjukkan bahwa gambaran EIC pada CT scan adalah prediktor signifikan terhadap sICH..$^{22}$ American Heart Association/American Stroke Association merekomendasikan tindakan trombolisis jika EIC bersifat ringan hingga sedang. ${ }^{4}$ 
Kadar glukosa awal dan riwayat diabetes dapat menjadi salah satu faktor risiko sICH. Dalam studi Prolyse in Acute Cerebral Thromboembolism Trial (PROACT), 36\% pasien dengan hiperglikemia (GDS $>200$ ) yang menjalani tPA intrarterial mengalami perdarahan intraserebral dengan risiko relatif $4,2,23$ serupa dengan studi NINDS. Penelitian Putaala dkk, menunjukkan hiperglikemia yang berlanjut hingga 48 jam pascatrombolisis berhubungan dengan luaran klinis yang buruk, termasuk sICH dan kematian. ${ }^{24}$ Nilai glukosa $>50 \mathrm{mg} / \mathrm{dL}$ menjadi salah satu acuan untuk tindakan trombolisis. ${ }^{4}$

Keadaan lain yang berpengaruh terhadap komplikasi tindakan adalah hipertensi. Sebuah studi menyatakan angka kejadian sICH pada pasien hipertensi tidak terkontrol mencapai $26 \%$, dibandingkan pada hipertensi terkontrol, yaitu $12 \% .{ }^{25}$ Oleh karena itu, studi NINDS memberikan target untuk tekanan darah pra-terapi $<185 / 110 \mathrm{mmHg}$ dan pascaterapi $<180 / 105 \mathrm{mmHg}$. ${ }^{4,12}$

Hampir 30\% pasien yang membutuhkan terapi tPA sebelumnya telah menggunakan aspirin atau antiplatelet lain. ${ }^{26}$ Hermann dkk, menyimpulkan terapi dual-antiplatelet (aspirin dan klopidogrel) berhubungan dengan risiko ICH yang meningkat secara signifikan dengan RO 9,29. ${ }^{27}$ Studi Pan dkk, menunjukkan potensi peningkatan risiko $\mathrm{sICH}$ pada orang yang memiliki riwayat penggunaan dual-aantiplatelet sebesar $14 \% .{ }^{28}$ Penggunaan satu macam antiplatelet tidak berdampak signifikan terhadap sICH, dibuktikan melalui studi Meurer dkk. ${ }^{29}$ Panduan AHA/ASA sendiri menegaskan bahwa penggunaan antiplatelet, baik tunggal atau kombinasi, tidak menjadi halangan untuk tindakan trombolisis, apabila manfaat reperfusi lebih besar dari risiko perdarahan intrakranial. ${ }^{4}$

Terdapat beberapa faktor lain yang berpotensi berpengaruh dengan sICH; faktor risiko kardiovaskular, seperti fibrilasi atrium dan gagal jantung kongestif, terkait dengan luaran stroke yang buruk dan terjadinya sICH. ${ }^{19}$ Pada panduan AHA/ASA, peningkatan nilai aPTT pada pasien gagal ginjal kronik membuat risiko perdarahan meningkat. ${ }^{4}$ Rendahnya kadar platelet juga dihubungkan dengan peningkatan risiko $\mathrm{sICH}$ sebesar 1,73 kali lipat, dan dicantumkan sebagai salah satu kriteria eksklusi tindakan ini apabila bernilai $<100.000 / \mathrm{mm}^{3}{ }^{30}$ Namun, kondisi trombositopenia juga dihubungkan dengan luaran yang lebih baik dan mortalitas yang lebih rendah. ${ }^{30}$ Bahkan studi Mowla dkk, menunjukkan bahwa penggunaan alteplase tetap aman pada pasien dengan kadar trombosit $<100.000$ / $\mathrm{mm}^{3} .{ }^{31}$

Gambaran radiologis khas berupa leukoaraiosis atau kerusakan iskemik kronik pada mikrosirkulasi otak menjadi salah satu prediktor sICH dan luaran yang buruk. ${ }^{32}$ Studi metaanalisis menunjukkan risiko sICH ditemukan lebih tinggi pada pasien dengan leukoaraiosis (RO:1,55) atau leukoaraiosis berat (RO:2,53). Leukoaraiosis juga menjadi prediktor independen sICH dalam 6 studi berbeda. ${ }^{32}$ Studi Kongbunkiat dkk juga menunjukkan bahwa kondisi leukoaraiosis serta derajatnya secara konsisten berhubungan dengan peningkatan risiko sICH dan perburukan luaran fungsional pada pasien yang menjalani terapi trombolisis..$^{33}$

Bila terdapat komplikasi trombolisis, hal yang pertama dilakukan ialah menghentikan infus alteplase/r-tPA. Jika pasien dicurigai mengalami sICH, pemeriksaan diagnostik harus segera dilakukan, mencakup pemeriksaan lab (darah lengkap, uji hemostasis, dan kadar fibrinogen) dan CT scan nonkontras. Setelah dipastikan sICH, diberikan infus kriopresipitat sebanyak 10IU selama 10-30 menit dan asam traneksamat IV $1000 \mathrm{mg}$. Selanjutnya diberikan terapi suportif, mencakup pengaturan tekanan darah, tekanan intrakranial, suhu, maupun kadar glukosa darah. $^{4}$

Jika komplikasi yang timbul berupa angioedema orolingual, tindakan pertama ialah pertahankan jalan napas sesuai prinsip kegawatdaruratan, dilanjutkan bolus metilprednisolon IV $125 \mathrm{mg}$ dan difenhidramin IV 50mg. Bila edema terus meluas, dapat dilanjutkan pemberian epinefrin subkutan $0,3 \mathrm{~mL}$ atau via nebulizer sebanyak $0,5 \mathrm{~mL}$. Pasien juga diberikan ranitidin IV 50mg serta terapi suportif jika kondisi stabil. ${ }^{4}$

\section{Perbandingan Prediktor sICH: Telaah Studi}

Faktor-faktor yang terkait dengan sICH telah banyak diteliti, namun sayangnya sebagian 
besar faktor-faktor ini umumnya berhubungan satu sama lain. Contohnya adalah fibrilasi atrium, penggunaan warfarin, usia, dan derajat stroke. Hal ini menyebabkan sulitnya menentukan penambahan risiko (independent additive risk) tiap variabel. Selain itu, risiko absolut yang menyertai faktor-faktor ini juga sangat bervariasi. ${ }^{13}$ Keterbatasan ini mendorong peneliti untuk membuat suatu sistem skor atau instrumen yang menggabungkan berbagai variabel sehingga didapatkan penilaian risiko yang lebih akurat. Sampai saat ini, terdapat 7 instrumen yang telah diciptakan, dengan nilai prediktif yang dapat dibandingkan satu sama lain. Instumen-instumen tersebut tercantum dalam Tabel $1 .{ }^{13}$

Penelitian lanjutan selanjutnya dilakukan untuk validasi berbagai instumen ini. Efektivitas sistem skor ini bervariasi antar studi. Pada studi WatsonFargie dkk, skor Hemorrhage After Thrombolysis (HAT) memiliki nilai prediktif tertinggi, dengan area under curve (AUC) sebesar 0,67-0,78. ${ }^{34}$ Sementara itu, studi Lokeskrawee $\mathrm{dkk}$, menunjukkan bahwa skor blood sugar, early infarct signs, hyperdense cerebral artery sign, age, NIHSS (SEDAN) memiliki nilai prediksi risiko tertinggi, dengan AUC sebesar 0,77. ${ }^{15}$ Penelitian Strbian dkk juga menunjukkan hasil serupa. ${ }^{11}$
Walaupun instrumen dapat memprediksi terjadinya risiko sICH dengan akurat, penundaan terapi trombolisis pada pasien dengan risiko $\mathrm{sICH}$ tinggi tidak dibenarkan. Pasien dengan yang memiliki prediksi risiko sICH tertinggi cenderung memiliki luaran yang sangat buruk apabila tidak ditatalaksana dengan trombolisis. ${ }^{13} \mathrm{Hal}$ ini sesuai dengan penelitian Whiteley dkk yang menyatakan manfaat terbesar penggunaan trombolisis adalah pasien-pasien yang memiliki risiko prediksi tertinggi $\mathrm{sICH}{ }^{35}$

Oleh karena itu, kuantifikasi risiko sICH dapat berguna untuk edukasi terhadap pasien dan keluarga terkait potensi komplikasi yang mungkin terjadi dan pemantauan ketat yang perlu dilakukan. Dapat disimpulkan bahwa, instrumen penilaian risiko tidak digunakan untuk menapis pasien yang dapat dilakukan trombolisis. ${ }^{13}$

\section{Pembuatan Keputusan Klinis}

Sebelum membuat suatu keputusan klinis, klinisi sebaiknya memberikan informasi sejelasjelasnya tentang manfaat tindakan dan komplikasi yang mungkin terjadi, beserta angka kejadiannya. Pemakaian instrumen penilaian risiko, seperti skor Hemorrhage After Thrombolysis (HAT) dapat bermanfaat, walau masih memerlukan validasi lebih lanjut. Hal ini diharapkan membantu klinisi dalam

Tabel 1. Perbandingan Skor Prediksi sICH ${ }^{13}$

\begin{tabular}{llc}
\hline Skor & Komponen Penilaian (Poin) & Kurva Karakteristik \\
\hline MSS & Usia, skor NIHSS, glukosa, trombosit (0-4) & $0,59-0,86$ \\
HAT & $\begin{array}{l}\text { Skor NIHSS, glukosa atau diabetes melitus, } \\
\text { hipodensitas awal pada CT scan }(0-5)\end{array}$ & $0,59-0,79$ \\
SEDAN & Usia, skor NIHSS, glukosa, tanda hiperdensitas arteri & $0,50-0,70$ \\
& serebri media, hipodensitas awal pada CT scan (0-5) & \\
SITS-ICH & Usia, skor NIHSS, glukosa, berat badan, hipertensi, & $0,58-0,76$ \\
& $\begin{array}{l}\text { riwayat pemakaian antiplatelet, tekanan darah } \\
\text { sistolik, interval awitan-tindakan (0-12) }\end{array}$ & \\
GRASPS GWTG & Usia, skor NIHSS, glukosa, tekanan darah sistolik, & $0,61-0,83$ \\
THRIVE & ras Asia dan non-Asia (0-101) & \\
Usia, skor NIHSS, hipertensi, diabetes melitus, & 0,6 \\
fibAN-100 & Usia, skor NIHSS (0-1) & $0,55-0,57$ \\
\hline
\end{tabular}

MSS: Multicenter Stroke Survey; NIHSS: National Institutes of Health Stroke Scale; HAT: Hemorrhage After Thrombolysis; SEDAN: blood sugar, early infarct signs, hyperdense cerebral artery sign, age, NIHSS; SITS-ICH: Safe Implementation of Thrombolysis in StrokeIntracranial Hemorrhage; GRASPS: [glucose at presentation, race (Asian), age, sex (male)], systolic blood pressure at presentation, and severity of stroke at presentation); GWTG: Get With The Guidelines; THRIVE: Totaled Health Risks in Vascular Events; SPAN: Stroke Prognostication Using Age and NIHSS; sICH: symptomatic intracerebral hemorrhage. 
menentukan keputusan, selain mengikuti pedoman trombolisis yang sudah terstandar.

Ketidakpatuhan terhadap pedoman umum dijumpai, yaitu sekitar $16-32 \%$ di segala tingkat layanan kesehatan. ${ }^{36}$ Pedoman yang dilanggar umumnya terkait kriteria inklusi dan eksklusi, protokol tekanan darah pascaterapi, dan penggunaan antiplatelet/antikoagulan. Institusi yang sering melanggar pedoman trombolisis $(66,7 \%)$ memiliki tingkat mortalitas tertinggi $(25,4 \%)$ dan meningkatkan angka kejadian $\mathrm{sICH} \cdot{ }^{37}$ Demikian pula angka kejadian sICH pada institusi yang tidak mematuhi pedoman adalah $38 \%$, jauh lebih tinggi dari pada yang mematuhinya, yaitu 5\%. ${ }^{36}$ Aspek pedoman trombolisis yang terkait $\mathrm{sICH}$ antara lain stroke atau trauma kepala dalam jangka 3 bulan, riwayat perdarahan intrakranial, dan penggunaan antikoagulan dengan INR $>1,7 \cdot 36-37$ Oleh karena itu, pemberian terapi yang tepat dapat memberikan manfaat maksimal serta mengurangi risiko seminimal mungkin.

\section{KESIMPULAN}

Tindakan trombolisis masih menjadi tindakan definitif pada kasus stroke iskemik, Risiko sICH tinggi melalui penilaian prediktor risiko perdarahan tidak dibenarkan menjadi alasan penundaan tindakan. Risiko komplikasi dapat diminimalisasi melalui kepatuhan terhadap panduan dan algoritma tindakan yang telah ditetapkan.

\section{DAFTAR PUSTAKA}

1. Benjamin EJ, Blaha MJ, Chiuve SE, Cushman M, Das SR, Deo R, dkk. Heart disease and stroke statistics 2017 update. Circulation. 2017;135(10):e146-603.

2. Seshadri S, Wolf PA. Lifetime risk of stroke and dementia: current concepts, and estimates from the Framingham Study. Lancet Neurol. 2007;6:1106-14.

3. Feigin VL, Krishnamurthi RV, Parmar P, Norrving B, Mensah GA, Bennett DA, dkk. Update on the global burden of ischemic and hemorrhagic stroke in 1990-2013: the GBD 2013 study. Neuroepidemiol. 2015;45:161-76.

4. Powers WJ, Rabinstein AA, Ackerson T, Adeoye OM, Bambakidis NC, Becker K, dkk. 2018 Guidelines for the early management of patients with acute ischemic stroke: a guideline for healthcare professionals from the American Heart Association/American Stroke Association. Stroke. 2018;49:e1-65.
5. Hacke W, Kaste M, Bluhmki E, Brozman M, Davalos A, Guidetti D, dkk. Thrombolysis with alteplase 3 to 4.5 hours after acute ischemic stroke. N Engl J Med. 2008;359(13):1317-29.

6. Wardlaw JM, Murray V, Berge E, del Zoppo G, Sandercock P, Lindley RL, dkk. Recombinant tissue plasminogen activator for acute ischaemic stroke: an updated systematic review and meta-analysis. Lancet. 2012;379:2364-72.

7. Saver JL, Fonarow GC, Smith EE, Reeves MJ, GrauSepulveda MV, Pan W, dkk. Time to treatment with intravenous tissue plasminogen activator and outcome from acute ischemic stroke. JAMA. 2013;309:2480-8.

8. Aguilar MI, Demaerschalk BM. Intracerebral hemorrhage. Semin Neurol. 2007;27(4):376-84.

9. Kostulas N, Larsson M, Kall TB, Euler MV, Nathanson D. Safety of thrombolysis in stroke mimics: an observational cohort study from an urban teaching hospital in Sweden. BMJ Open. 2017;7:e016311

10. Yaghi S, Eisenberger A, Willey JZ. Symptomatic intracerebral hemorrhage in acute ischemic stroke after thrombolysis with intravenous recombinant tissue plasminogen activator. JAMA Neurol. 2014;71(9):1181-5.

11. Strbian D, Michel P, Seiffge DJ, Numminen H, Meretoja A, Murao K, dkk. Symptomatic intracranial hemorrhage after stroke thrombolysis comparison of prediction scores. Stroke. 2014;45:752-8.

12. The NINDS t-PA Stroke Study Group. Intracerebral hemorrhage after intravenous t-PA therapy for ischemic stroke. Stroke. 1997;28(11):2109-18.

13. Yahgi S, Willey JZ, Cucchiara B, Goldstein JN, Gonzales NR, Khatri P. Treatment and outcome of hemorrhagic transformation after intravenous alteplase in acute ischemic stroke: a scientific statement for healthcare professionals from American Heart Association/American Stroke Association (AHA/ASA). Stroke. 2017;48(12):e343-61.

14. Brown DL, Barsan WG, Lisabeth LD, Gallery ME, Morgenstern LB. Survey of emergency physicians about recombinant tissue plasminogen activator for acute ischemic stroke. Ann Emerg Med. 2005;46(1):56-60.

15. Lokeskrawee T, Muengtaweepongsa S, Patumanond J, Tiamkao S, Thamangraksat T, Phankhian P. Prediction of symptomatic intracranial hemorrhage after intravenous thrombolysis in acute ischemic stroke: the symptomatic intracranial hemorrhage score. J Stroke Cerebrovasc. 2017;26(1): 2622-9.

16. Whiteley WN, Slot KB, Fernandes P, Sandercock P, Wardlaw J. Risk factors for intracranial hemorrhage in acute ischemic stroke patients treated with recombinant tissue plasminogen activator: a systematic 
review and meta-analysis of 55 studies. Stroke. 2012;43:2904-9.

17. Longstreth WT Jr, Katz R, Tirschwell DL, Cushman $\mathrm{M}$, Psaty BM. Intravenous tissue plasminogen activator and stroke in the elderly. Am J Emerg Med. 2010;28(3):359-63.

18. Bluhmki E, Chamorro A, Davalos A, Sauce C, Wahlgren N, Machnig T, dkk. Stroke treatment with alteplase given 3.0-4.5 h after onset of acute ischaemic stroke (ECASS III): additional outcomes and subgroup analysis of a randomised controlled trial. Lancet Neurol. 2009;8(12):1095-102.

19. Wahlgren $\mathrm{N}$, Ahmed $\mathrm{N}$, Eriksson $\mathrm{N}$, Aichner F, Bluhmki E, Davalos A, dkk. Multivariable analysis of outcome predictors and adjustment of main outcome results to baseline data profile in randomized controlled trials: Safe Implementation of Thrombolysis in Stroke-MOnitoring STudy (SITSMOST). Stroke. 2008;39(12):3316-22.

20. Liu M, Pan Y, Zhou L, Wang Y. Predictors of postthrombolysis symptomatic intracranial hemorrhage in Chinese patients with acute ischemic stroke. PLoS One. 2017;12(9):e0184646.

21. Bentley P, Ganesalingam J, Jones ALC, Mahady $\mathrm{K}$, Epton S, Rinne P, dkk. Prediction of stroke thrombolysis outcome using CT brain machine learning. Neuroimage Clin. 2014;4:635-40.

22. Cucchiara B, Kasner SE, Tanne D, Levine SR, Demchuk A, Messe SR, dkk. Factors associated with intracerebral hemorrhage after thrombolytic therapy for ischemic stroke: pooled analysis of placebo data from the Stroke-Acute Ischemic NXY Treatment (SAINT) I and SAINT II Trials. Stroke. 2009;40(9):3067-72.

23. Kase CS, Furlan AJ, Wechsler LR, Higashida RT, Rowley HA, Hart RG, dkk. Cerebral hemorrhage after intra-arterial thrombolysis for ischemic stroke: the PROACT II trial. Neurology. 2001;57(9):160310 .

24. Putaala J, Sairanen T, Meretoja A, Lindsberg PJ, Tiainen M, Liebkind R, dkk. Post-thrombolytic hyperglycemia and 3-month outcome in acute ischemic stroke. Cerebrovasc Dis. 2011;31(1):83-92.

25. Tsivgoulis G, Frey JL, Flaster M, Sharma VK, Lao AY, Hoover SL, dkk. Pre-tissue plasminogen activator blood pressure levels and risk of symptomatic intracerebral hemorrhage. Stroke. 2009;40(11):3631-4.

26. Dorado L, Millan M, de la Ossa NP, Guerrero C, Gomis M, Lopez-Cancio E, dkk. Influence of antiplatelet pre-treatment on the risk of intracranial haemorrhage in acute ischaemic stroke after intravenous thrombolysis. Eur J Neurol. 2009;17(2):301-6.
27. Hermann A, Dzialowski I, Koch R, Gahn G. Combined anti-platelet therapy with aspirin and clopidogrel: risk factor for thrombolysis-related intracerebral hemorrhage in acute ischemic stroke? J Neurol Sci. 2009;284(1-2):155-7.

28. Pan Y, Chen Q, Liai X, Zhao X, Wang C, Liu C, dkk. Preexisting dual antiplatelet treatment increases the risk of post-thrombolysis intracranial hemorrhage in Chinese stroke patients. Neurol Res. 2015;37(1):648.

29. Meurer WJ, Kwok H, Skolarus LE, Adelman EE, Kade AM, Kalbfleisch J, dkk. Does pre-existing antiplatelet treatment influence post-thrombolysis intracranial hemorrhage in community-treated ischemic stroke patients? An observational study. Acad Emerg Med. 2013;20(2):146-54.

30. Gensicke H, Al Sultan AS, Strbian D, Hametner C, Zinkstok SM, Moulin S, dkk. Intravenous thrombolysis and platelet count. Neurology. 2018;90(8):e690-7.

31. Mowla A, Kamal H, Lail NS, Vaughn C, SHirani P, Mehla S, dkk. Intravenous thrombolysis for acute ischemic stroke in patients with thrombocytopenia. J Stroke Cerebrovasc Dis. 2017;26(7):1414-8.

32. Charidimou A, Pasi M, Fiorelli M, Shams S, von Kummer R, Pantoni L, dkk. Leukoaraiosis, cerebral hemorrhage, and outcome after intravenous thrombolysis for acute ischemic stroke: a metaanalysis. Stroke. 2016;47(9):2346-72.

33. Kongnunkiat K, Wilson D, Kasemsap N, Tiamkao S, Jichi F, Palumbo V, dkk. Leukoaraiosis, intracerebral hemorrhage, and functional outcome after acute stroke thrombolysis. Neurology. 2017;88(7):636-45.

34. Watson-Fargie T, Dai D, MacLeod MJ, Reid JM. Comparison of predictive scores of symptomatic intracerebral haemorrhage after stroke thrombolysis in a single centre. J R Coll Physicians Edinb. 2015;45:127-32.

35. Whiteley WN, Thompson D, Murray G, Cohen G, Lindley RI, Wardlaw J, dkk. Targeting recombinant tissue-type plasminogen activator in acute ischemic stroke based on risk of intracranial hemorrhage or poor functional outcome: an analysis of the third international stroke trial. Stroke. 2014;45:1000-6.

36. Lopez-Yunez AM, Bruno A, Williams LS, Yilmaz E, Zurru C, Biller J. Protocol violations in communitybased rTPA stroke treatment are associated with symptomatic intracerebral hemorrhage. Stroke. 2001;32(1):12-6.

37. Graham GD. Tissue plasminogen activator for acute ischemic stroke in clinical practice: a meta-analysis of safety data. Stroke. 2003;34(12):2847-50. 